\title{
Characterization of a Pepper Vein Banding Virus from Chili Pepper in India
}

\author{
K. S. Ravi, Department of Plant Pathology, University of Agricultural Sciences; J. Joseph, Department of Bio- \\ chemistry, Indian Institute of Science; N. Nagaraju, Department of Plant Pathology, University of Agricultural \\ Sciences; S. Krishna Prasad, Department of Biochemistry, Indian Institute of Science; H. R. Reddy, Department \\ of Plant Pathology, University of Agricultural Sciences; and H. S. Savithri, Department of Biochemistry, Indian \\ Institute of Science, Bangalore, India
}

\begin{abstract}
Ravi, K. S., Joseph, J., Nagaraju, N., Krishna Prasad, S., Reddy, H. R., and Savithri, H. S. 1997. Characterization of a pepper vein banding virus from chili pepper in India. Plant Dis. 81:673676.

A survey conducted in pepper-growing tracts of Karnataka State, covering 165 fields in 33 villages, revealed the occurrence of many pepper mosaic diseases. Based on reactions on selected test plants, the viruses were identified as pepper vein banding virus (PVBV), pepper veinal mottle virus, potato virus $\mathrm{Y}$, cucumber mosaic virus, and tobacco mosaic virus. Among these, PVBV was the most prevalent. PVBV was purified from infected leaves of Capsicum апnиит cv. California Wonder. Electron microscopy revealed flexuous rod-shaped particles in the purified preparations. The coat protein (CP) molecular weight was 35,000, which is similar to members of the Potyvirus group. As in other potyviruses, the CP underwent proteolytic degradation to a fragment with a molecular weight of 31,000. Both of these bands cross-reacted with antibodies against tobacco etch virus in Western blots. Polyclonal antibodies were produced against PVBV. Cross-reactivity studies with other potyviral antisera showed that PVBV is serologically closer to peanut mottle virus than to peanut stripe virus or sorghum potyvirus. Nterminal sequence analysis of the intact $\mathrm{CP}$ and trypsin-resistant core revealed that PVBV is a distinct member of the Potyvirus group.
\end{abstract}

One of the major constraints to the production of pepper, which is an economically important crop in India, is infection by viruses. There are about 10 different viruses reported to infect pepper in India $(2,5,9)$. Identification of these viruses has been done based on the symptoms produced on a set of test plant species and, in some instances, the serological relationships of the virus with other well-characterized group members. However, molecular characterization has not been reported for any of these isolates.

In the current paper, we report the occurrence of pepper vein banding virus (PVBV), pepper veinal mottle virus (PVMV), potato virus Y (PVY), cucumber mosaic virus (CMV), and tobacco mosaic virus (TMV) in the pepper-growing tracts of Karnataka State, India. Further, we report the purification and characterization of PVBV, which is the most prevalent virus among those infecting peppers, and show that it is a distinct member of the Potyvirus group.

Corresponding author: H. S. Savithri

E-mail: bchss@biochem.iisc.ernet.in

Accepted for publication 14 March 1997.

Publication no. D-1997-0421-04R

(C) 1997 The American Phytopathological Society

\section{MATERIALS AND METHODS}

Survey and collection of pepper mosaic isolates. To determine the prevalence of chili mosaic viruses in nature, a survey was undertaken around the Kolar and Shimoga districts of Karnataka State during 1987 to 1988 . The age of the pepper crop surveyed varied from 2 to 4 months. At the village level, every fifth field was selected for observation and collection of virus isolates. In each field, five rows were randomly selected, and the total number of plants and the number of plants showing mosaic and other associated symptoms were recorded to calculate the percentage of diseased plants. Simultaneously, two plants in each of these five rows were selected randomly for collection of leaf samples. The samples collected were used subsequently to inoculate healthy seedlings of Capsicum annuum cvs. California Wonder and Byadagi Kaddi that were maintained under insect-proof conditions for symptom expression. Further, the isolates were inoculated to a set of test plants, as described by Prasad Rao and Yaraguntaiah (9), to group the viruses.

PVBV virion purification. Leaves harvested from infected pepper (C. апnиит $\mathrm{cv}$. California Wonder) (Fig. 1) at 3 weeks postinoculation were ground in $0.02 \mathrm{M} \mathrm{N}$-2hydroxyethylpiperazine- $N^{\prime}$-2-ethanesulfonic acid (HEPES) buffer (1:2 wt/vol), $\mathrm{pH}$ 7.5 , containing $1 \mathrm{M}$ urea, $1 \%$ Triton $\mathrm{X}$ -
100, $10 \mathrm{mM}$ diethyl dithiocarbamate, and $0.1 \% \beta$-mercaptoethanol. The extract was passed through cheesecloth, and the filtrate was clarified with $10 \%$ ice-cold chloroform. The virus was precipitated by adding $6 \%$ polyethylene glycol 6000 and $0.2 \mathrm{M}$ $\mathrm{NaCl}$. The precipitate was suspended in resuspension buffer (0.02 M HEPES, $\mathrm{pH} 7.5$, containing $0.5 \mathrm{M}$ urea and $0.02 \mathrm{M}$ sodium sulfite), layered over 10 to $40 \%$ preformed sucrose density gradient prepared in the same buffer, and subjected to centrifugation at $92,500 \times g$ for $3 \mathrm{~h}$ at $4^{\circ} \mathrm{C}$ in a SW 28 rotor. Fractions collected at the end of the run were monitored for absorbance at 280 and $260 \mathrm{~nm}$. The peak fractions were pooled and pelleted by centrifugation at $120,000 \times g$ for $3 \mathrm{~h}$ at $4^{\circ} \mathrm{C}$. The final pellet was resuspended in a minimum volume of resuspension buffer and was used for further studies. Purified PVBV samples applied on Formvar-coated grids were stained with $1 \%$ uranyl acetate (4) and examined under a JEOL (Tokyo) 100S transmission electron microscope operating at 80 to $100 \mathrm{kV}$.

Production of polyclonal antisera and enzyme-linked immunosorbent assay (ELISA). Antisera were produced in rabbits against purified virions of PVBV by giving a series of intradermal injections: $500 \mu \mathrm{g}$ of virus in complete adjuvant for the first injection and $250 \mu \mathrm{g}$ of virus in incomplete adjuvant for three subsequent injections at 1-week intervals. A booster dose of $250 \mu \mathrm{g}$ of virus in PBS $(0.1 \mathrm{M}$ potassium phosphate buffer containing $0.9 \%$ sodium chloride, wt/vol) was administered intramuscularly 10 days prior to bleeding. The presence of PVBV-specific antibodies in the serum was tested by direct antigen coating-ELISA (DAC-ELISA) (8). Flatbottomed polystyrene microtiter plates (NuncImmuno plate, Polysorp, Roskilde, Denmark) were precoated with $100 \mathrm{ng}$ of purified PVBV in $0.05 \mathrm{M}$ sodium carbonate buffer (pH 9.6) per well. The binding of antibodies in the serum to the antigen was assayed with goat anti-rabbit immunoglobulin (Ig) conjugated to alkaline phosphatase. The absorbance was read at $405 \mathrm{~nm}$ in a Bio-Tek (Winooski, VT) microplate autoreader EL 311. All the assays were carried out in duplicates with normal rabbit serum as the negative control. The average of the duplicates is presented. 
Western blot analysis. The PVBV coat protein $(\mathrm{CP})$ was subjected to $12.5 \%$ sodium dodecyl sulfate-polyacrylamide gel electrophoresis (SDS-PAGE) (6). After electrophoresis, the proteins were transferred to nitrocellulose membrane with Pharmacia (Uppsala, Sweden) Novoblot apparatus at a constant current of $0.75 \mathrm{~mA} / \mathrm{cm}^{2}$ of membrane for $2 \mathrm{~h}$. The unoccupied sites were blocked with 5\% milk powder for $1 \mathrm{~h}$. Polyclonal antiserum to tobacco etch virus (TEV) (1:1,000 dilution) was added and incubated at $37^{\circ} \mathrm{C}$ for $2 \mathrm{~h}$. Peroxidase conjugated to goat anti-rabbit Ig was used as the secondary antibody for detection (12).

N-terminal sequencing of PVBV CP. Purified virions of PVBV were treated with trypsin $(2 \mu \mathrm{g}$ of virus per $\mathrm{ml})$ at $20^{\circ} \mathrm{C}$ for $30 \mathrm{~min}$ to obtain the trypsin-resistant core (TRC) of the CP. The intact PVBV CP and the TRC, separated on $12.5 \%$ SDS-PAGE, were transferred to polyvinylidene difluoride membrane (7), and the $\mathrm{N}$-terminal sequences of the proteins were determined by loading the cut membrane directly onto an automated gas phase sequencer, Shimadzu PSQ-1 (Shimadzu Corporation, Kyoto, Japan).

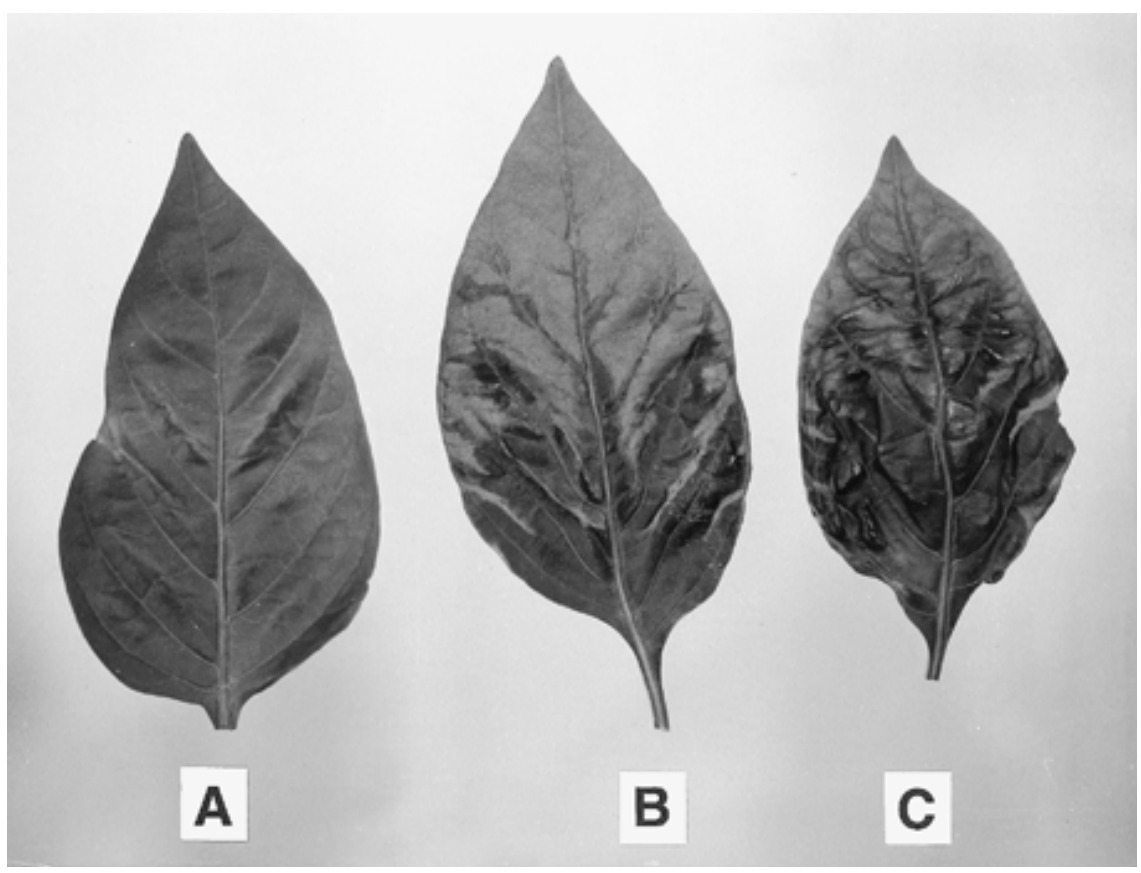

Fig. 1. Vein banding symptoms on leaves of Capsicum annuum cv. California Wonder induced by pepper vein banding virus (PVBV). (A) healthy leaf; (B and C) PVBV-infected leaves.

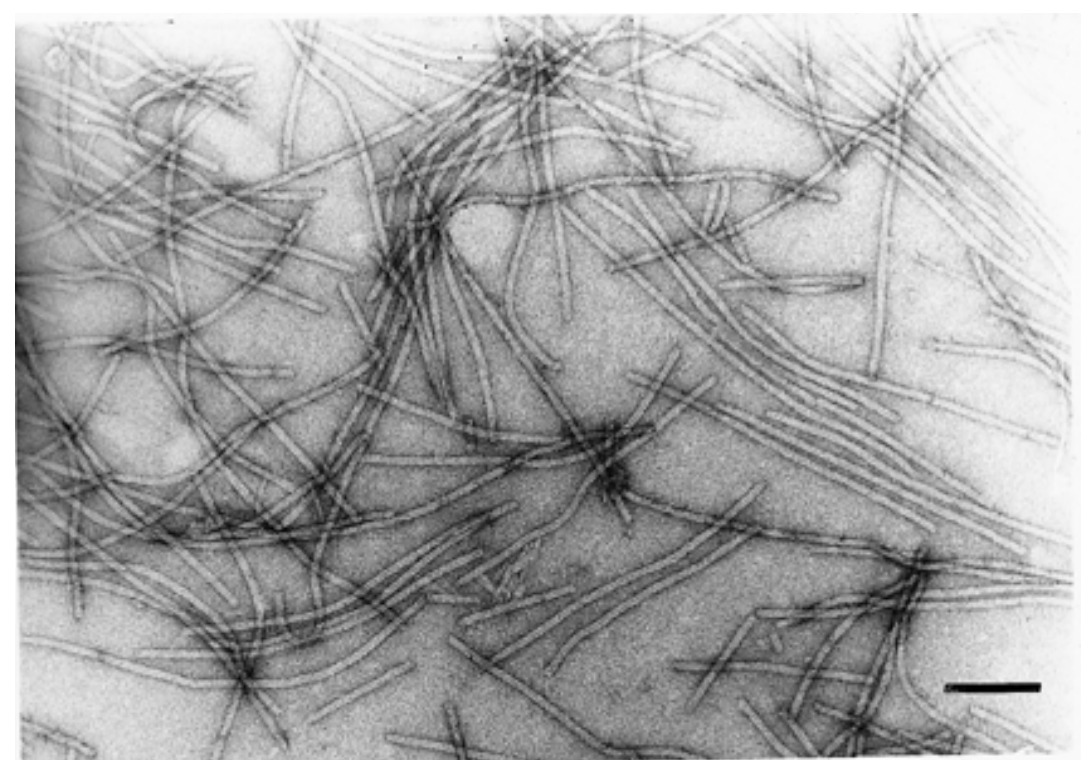

Fig. 2. Electron micrograph of purified pepper vein banding virus virions stained with $1 \%$ uranyl acetate. $\mathrm{Bar}=250 \mathrm{~nm}$.

\section{RESULTS}

Survey of pepper mosaic diseases in Karnataka State. The survey conducted in pepper-growing tracts of Karnataka State, covering 165 fields in 33 villages, revealed the widespread occurrence of pepper mosaic diseases. In different taluks of the Kolar District, under irrigated conditions the incidence of mosaic disease ranged from 15 to $31 \%$, with an average of $25 \%$, of the plants surveyed. In the Shimoga District, incidence under rain-fed conditions ranged from 37 to $58 \%$, with an average of $47 \%$, of the plants surveyed. Of the 66 pepper plants with mosaic collected from the fields (Kolar and Shimoga districts), 10\% were not sap-infective, and $13 \%$ had mixed virus infections. Based on their reactions on selected test plants, sap-transmissible virus isolates of PVBV (27\%), PVMV (18\%), CMV (15\%), PVY (8\%), and TMV (6\%) were identified.

Characterization of PVBV. In hostrange studies, 56 species or cultivars be-

Table 1. Reactions of plants from the Solanaceae family to pepper vein banding virus

\begin{tabular}{|c|c|}
\hline Host & Symptoms $^{a}$ \\
\hline $\begin{array}{l}\text { Capsicum annuum L. } \\
\text { 'Byadagi Kaddi' }\end{array}$ & $\begin{array}{l}\text { VB, RT, EP, } \\
\text { RLS }\end{array}$ \\
\hline C. аппиит 'California Wonder' & VB, MM \\
\hline $\begin{array}{l}\text { Datura metal } \mathrm{L} . \\
\text { D. stramonium } \mathrm{L} .\end{array}$ & MM, LD, RLS \\
\hline Lycopersicon esculentum Mill. & MM, VB \\
\hline $\begin{array}{l}\text { Nicotiana bigelovii S. Wats. } \\
\text { N. debneyi Domin. }\end{array}$ & $\ldots$ \\
\hline$N$. glutinosa $\mathrm{L}$ & MM, LD \\
\hline N. hybrid L. & CS, VB, RLS \\
\hline $\begin{array}{l}\text { N. nudicaulis } \mathrm{S} \text {. Wats. } \\
\text { N. nesophila } \text { Roxb. }\end{array}$ & $\ldots$ \\
\hline N. occidentalis $\mathrm{L}$. & $\begin{array}{l}\text { VC, RLS, LD, } \\
\text { EP, SG }\end{array}$ \\
\hline N. plumbaginifolia Viv. & $\mathrm{VB}, \mathrm{MM}$ \\
\hline $\begin{array}{l}\text { N. rependa Wild. Ex Lm. } \\
\text { N. rosulata } \mathrm{L} \text {. }\end{array}$ & $\mathrm{LCR} / \mathrm{S}$ \\
\hline N rustica L. & SNLL, VN \\
\hline $\begin{array}{l}\text { N. simulans N.T. Burbidge } \\
\text { N. sylvestris Speg. \& Gomes }\end{array}$ & LCS, LD \\
\hline N. tabaccum L. 'Anand 119' & VB, LD \\
\hline N. tabaccum 'Candel' & $\mathrm{VB}, \mathrm{MM}$ \\
\hline N. tabaccum 'Delcrest' & VB, MM, LD \\
\hline N. tabaccum 'FCV special' & $\mathrm{VB}, \mathrm{MM}$ \\
\hline N. tabaccum 'GT-4' & VB, MM \\
\hline N. tabaccum 'GT-6' & VB, MM, LD \\
\hline N. tabaccum 'Hicks 103' & $\mathrm{VB}, \mathrm{MM}$ \\
\hline N. tabaccum 'Hicks special' & $\mathrm{VB}, \mathrm{MM}$ \\
\hline N. tabaccum 'РCT-7' & VB, MM, LD \\
\hline N. tabaccum 'PL-5' & VB \\
\hline N. tabaccum 'Prabha' & $\mathrm{VB}, \mathrm{MM}$ \\
\hline N. tabaccum 'Samsun' & $\mathrm{VB}, \mathrm{MM}$ \\
\hline N. tabaccum 'Sona' & $\mathrm{VB}, \mathrm{MM}$ \\
\hline N. tabaccum 'Swarna' & VB, MM \\
\hline N. tabaccum 'White Burley' & VB, MM, LD \\
\hline N. tabaccum 'Xanthi' & VB \\
\hline N. unulata $\mathrm{L}$. & NLL, VN \\
\hline
\end{tabular}

a $\ldots=$ No reaction; $\mathrm{RT}=$ rat tailing; $\mathrm{VB}=$ vein banding; RLS = reduction in leaf size; $\mathrm{CS}=$ chlorotic specks; LCR/S = local chlorotic rings/ spots; $\mathrm{MM}=$ mosaic mottling; SNLL = systemic necrotic local lesions; NLL $=$ necrotic local lesions; $\mathrm{LD}=$ leaf distortion; $\mathrm{VN}=$ veinal necrosis; $\mathrm{EP}=$ elongation of petiole; $\mathrm{SG}=$ stunted growth. 
longing to five families (Solanaceae, Chaenopodiaceae, Cruciferaceae, Cucurbitaceae, and Leguminaceae) were tested for infectivity by PVBV. Susceptibility to PVBV was confined to the family Solanaceae (Table 1). Symptoms produced in $C$. annuum cv. California Wonder included vein banding and mosaic mottling (Fig. 1).

Purified virion preparations gave a yield of 8 to $10 \mathrm{mg}$ of virus per $\mathrm{kg}$ of leaves. The major problem encountered during purification was the aggregation of the virion particles, which was minimized by use of $1 \mathrm{M}$ urea, $0.1 \% \quad \beta$-mercaptoethanol, and $1 \%$ Triton X-100 in the extraction buffer. Electron micrography of purified virions of PVBV showed that the particles were flexuous rods with an average length of 900 nm (Fig. 2). Using SDS-PAGE, the CP of PVBV was shown to have an approximate molecular weight of 35,000 . In addition to this band, another band with an approximate molecular weight of 31,000 was observed in most of the preparations. This second band could be a degradation product of the intact $\mathrm{CP}$, because the potyviral CPs are extremely susceptible to proteolytic degradation (11). Such a possibility was confirmed by Western blot analysis (Fig. 3B). Both bands reacted with antibodies to TEV in Western blot, confirming that PVBV is a potyvirus that is serologically related to TEV. The antibody dilution curve obtained with homologous antiserum identified a dilution end point of 1:128,000. In cross-reactivity studies, PVBV reacted well with peanut mottle virus (PeMoV) and peanut stripe virus (PStV) antisera but failed to react with sorghum potyvirus antiserum (Fig. 4).

The N-terminal sequence of the intact $\mathrm{CP}(35 \mathrm{~K})$ and the TRC $(30 \mathrm{~K})$ could be determined up to 16 and 18 amino acid residues, respectively. These sequences were compared with other potyviral $\mathrm{CP}$ sequences available in the protein databank (data not shown). The N-terminal amino acid sequence of intact $\mathrm{CP}$ showed not more than $30 \%$ identity with other potyviruses. However, the $\mathrm{N}$ terminus of the TRC had a significant homology with other potyviruses. A comparison of the $\mathrm{N}$ terminal sequences of the intact and TRC of the PVBV CP with the corresponding region in the $\mathrm{CP}$ sequences of other potyviruses infecting pepper is presented (Fig. 5). The N-terminal sequence of the PVBV $\mathrm{CP}$ encompassed the DAG sequence, which is present in aphid-transmitted potyviruses.

\section{DISCUSSION}

Our survey of the incidence of mosaic diseases in pepper in the extensively cultivated areas of southern Karnataka State revealed that PVBV was the predominant mosaic virus. This survey represents the usual disease incidence that is prevalent in this region, and the incidence was not particularly high during the year(s) of the survey. Based on an analysis of the symp-
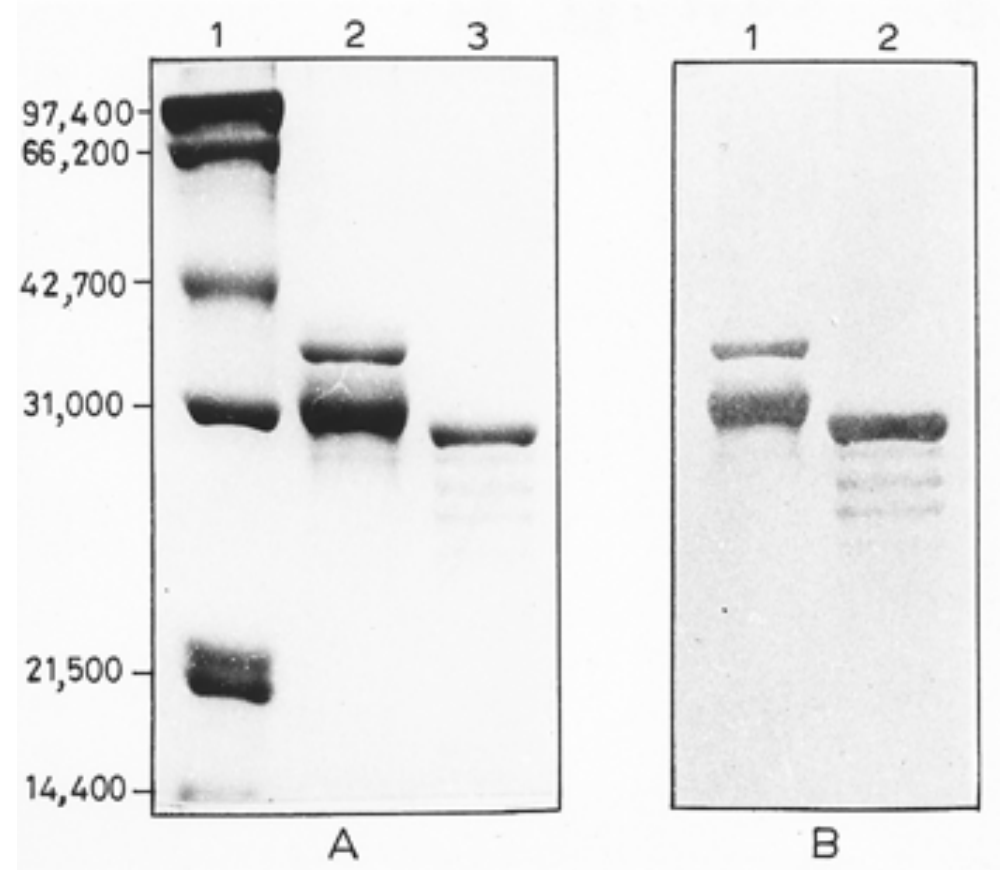

Fig. 3. Analysis of the pepper vein banding virus (PVBV) coat protein (CP). (A) Sodium dodecyl sulfate-polyacrylamide gel electrophoresis showing the PVBV CP. Lane 1, standard molecular weight markers. Lane 2, intact CP. Lane 3, trypsin-resistant core (TRC) of the CP. (B) Western blot analysis of the PVBV CP. Lane 1, intact CP. Lane 2, TCR of the CP.

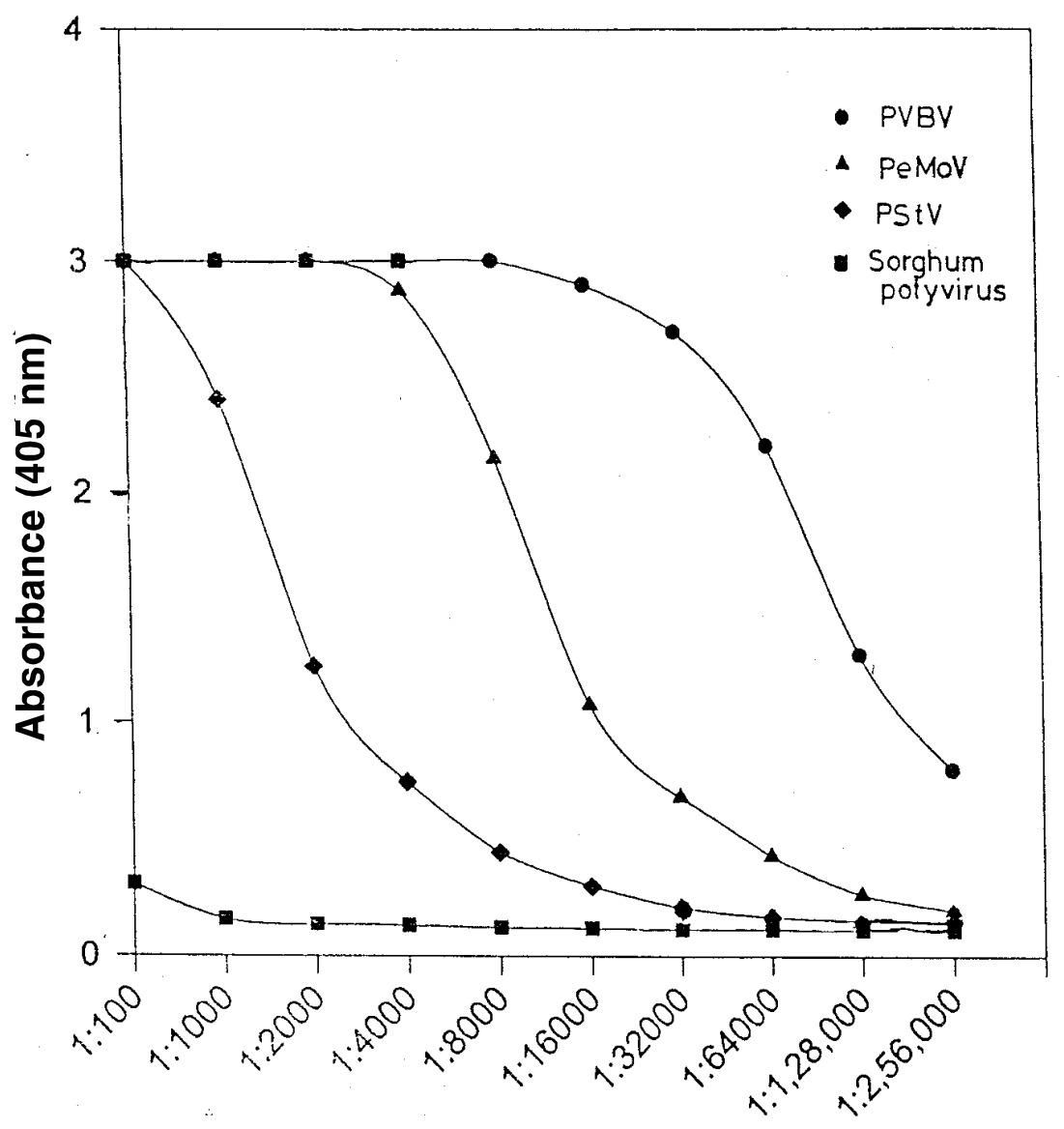

Serum dilution

Fig. 4. Cross-reactivity of pepper vein banding virus (PVBV) with other potyviral antisera. The antigen was $100 \mathrm{ng}$ of purified PVBV virions. Antisera were used at different dilutions. The antigen was detected by direct antigen-coating enzyme-linked immunosorbent assay. 
A

\begin{tabular}{|c|c|c|}
\hline PVBV & A G E $S$ V D A G S V K E D S $S$ & (this study) \\
\hline PVY - D & A N D T I D A G E S K K D A R & (10) \\
\hline PeMV & A N D T I D T G G N S K K D V K & (3) \\
\hline TEV - HAT & S G T V D A G A D A K K K D Q & (1) \\
\hline PepMoV & S S S R S D T L D A G E E K K K & (13) \\
\hline
\end{tabular}

B

\begin{tabular}{lll|ll|l|l|l|ll|lll|ll|lll} 
PVBV & D R & D V V N & V & G & T & S & G & T & F & T & I & P & R & L & K & (this study) \\
PVY - D & D R & D V V N & A & G & T & S & G & T & H & T & V & P & R & I & K & (10) \\
PeMV & E & K & D V V N & A & G & T & S & G & T & H & T & V & P & R & I & K & (3) \\
TEV - HAT & D R & D V V N & A & G & T & S & G & T & F & S & V & P & R & I & N & (1) \\
PepMoV & D S & D V V N & A & G & T & V & G & T & F & T & I & P & R & I & K & (13)
\end{tabular}

Fig. 5. N-terminal amino acid sequence comparison of (A) intact and (B) the trypsin-resistant core of coat proteins of pepper vein banding virus (PVBV); potato virus Y (PVY-D); pepper mottle virus, PVY strain (PeMV); tobacco etch virus (TEV-HAT); and pepper mottle virus (PepMoV) infecting pepper. References are given in parentheses. Blocked regions indicate the conserved amino acid residues. The DAG sequence in PVBV is underlined.

toms produced in C. annuum cv. California Wonder, the host-range experiments, and transmission studies, it was apparent that the isolate causing vein banding symptoms could be a potyvirus. Subsequently, glasshouse-grown $C$. annuum cv. California Wonder was inoculated mechanically with this isolate, and infected leaves were used for purification. The purified virus appeared as flexuous rods with an average length of $900 \mathrm{~nm}$, which is consistent with the morphology of potyviruses. The size of the $\mathrm{CP}$ was in the range expected for potyviruses. The CP of PVBV cross-reacted with antibodies against TEV (in Western blots), which is a well-characterized member of the Potyvirus group. A high-titer polyclonal antiserum for purified virions of PVBV was produced. The cross-reactivity studies with other potyviral antisera suggested that PVBV is closer serologically to $\mathrm{PeMoV}$ than to PStV. On the other hand, PVBV showed no cross-reactivity to sorghum potyvirus antiserum.

The N-terminal sequence of potyviral CPs varies in length as well as in sequence. However, strains of a distinct member show at least $90 \%$ homology (14). The Nterminal sequence of PVBV CP was compared with all the potyviral $\mathrm{CP}$ sequences available in the protein databank. The PVBV
$\mathrm{N}$-terminal sequence did not have more than $30 \%$ similarity with any of the reported potyviral CP sequences. This suggested that PVBV may be a distinct member of the Potyvirus group. However, the DAG sequence conserved in all aphid-transmitted potyviruses also was present in the $\mathrm{N}$-terminal sequence of the PVBV CP. Also, the N-terminal sequence of the TRC of PVBV showed that this region was extremely homologous with other potyviral CPs, confirming the identity of PVBV as a member of the Potyvirus group. The results presented in this paper demonstrate that PVBV is a distinct member of the Potyvirus group.

\section{ACKNOWLEDGMENTS}

This research was supported by the Indo-French Center for Promotion of Advanced Research, New Delhi; the Technology Development Mission, Government of India; and Rallis India Ltd. J. Joseph is a recipient of CSIR fellowship. We thank V. Krishnan, DBT Facility for Protein/peptide Sequencing, Department of Biochemistry, I.I.Sc., for assistance in sequencing the proteins reported in this paper; Y. N. Shamala, Bioinformatics Center, Department of Physics, I.I.Sc., for the database search and analysis of amino acid sequence; and $\mathrm{P}$. Sreenivasulu, Department of Virology, S.V. University, Tirupathi, and D. V. R. Reddy, ICRISAT, Hyderabad, for providing antisera to some potyviruses.
LITERATURE CITED

1. Allison, R. F., Dougherty, W. G., Parks, T. D., Wills, L., Johnston, R. E., and Armstrong, F. B. 1985. Biochemical analysis of capsid protein gene and capsid protein of tobacco etch virus: $\mathrm{N}$-terminal amino acids are located on the virion's surface. Virology 147:309-316.

2. Bidari, V. B., and Reddy, H. R. 1983. Prevalence of chilli viruses in Dharwad district. Plant Pathol. Newsl. 1:11-12.

3. Dougherty, W. G., Allison, R. F., Parks, T. D., Johnston, R. E., Field, M. J., and Armstrong, F. B. 1985. Nucleotide sequence of the $3^{\prime}$ terminus of pepper mottle virus genomic RNA: Evidence for an alternative mode of potyvirus capsid protein gene organization. Virology 146: 282-291.

4. Hatta, T., and Francki, R. B. I. 1984. Differences in the morphology of isometric particles of some plant viruses stained with uranyl acetate as an aid to their identification. J. Virol. Methods 9:237-247.

5. Joshi, R. D., and Bhargava, K. S. 1962. A vein banding mosaic virus disease of chillies (Capsicum frutescens L.). Indian J. Microbiol. 2:29-34.

6. Laemmli, U. K. 1970. Cleavage of structural proteins during the assembly of the head of bacteriophage T-4. Nature (Lond.) 227:680-685.

7. Matsudaria, P. 1987. Sequence from picomole quantities of proteins electroblotted onto polyvinylidene difluoride membranes. J. Biol. Chem. 263:10035-10038.

8. Mowat, W. P., and Dawson, S. 1987. Detection and identification of plant viruses by ELISA using crude-sap extracts and unfractioned antisera. J. Virol. Methods 15:233-247.

9. Prasad Rao, R. D. V. J., and Yaraguntaiah, R. C. 1979. A key for diagnosis of some chilli viruses. Mysore J. Agric. Sci. 13:442-445.

10. Shukla, D. D., Inglis, A. S., McKern N. M., and Gough, K. H. 1986. Coat proteins of potyviruses. 2. Amino acid sequence of coat protein of potato virus Y. Virology 152:118125.

11. Shukla, D. D., and Ward, C. W. 1989. Structure of potyvirus coat proteins and its application in the taxonomy of the Potyvirus group. Adv. Virus Res. 36:273-314.

12. Towbin, H., Stachelin, T., and Gordon, J. 1979. Electrophoretic transfer of proteins from polyacrylamide gels to nitrocellulosic sheets: Procedure and some applications. Proc. Natl. Acad. Sci. USA 75:4350-4354.

13. Vance, V. B., Jordan, R., Edwardson, J. R., Christie, R., Purcifull, D. E., Turpen, T., and Falk, B. 1992. Evidence that pepper mottle virus and potato virus $\mathrm{Y}$ are distinct viruses: Analysis of the coat protein and $3^{\prime}$ untranslated sequence of a California isolate of pepper mottle virus. Arch. Virol. Suppl. 5:337345 .

14. Ward, C. W., McKern, N. M., Frenkel, M. J., and Shukla, D. D. 1992. Sequence data as the major criterion for potyvirus classification. Arch. Virol. Suppl. 5:283-297. 